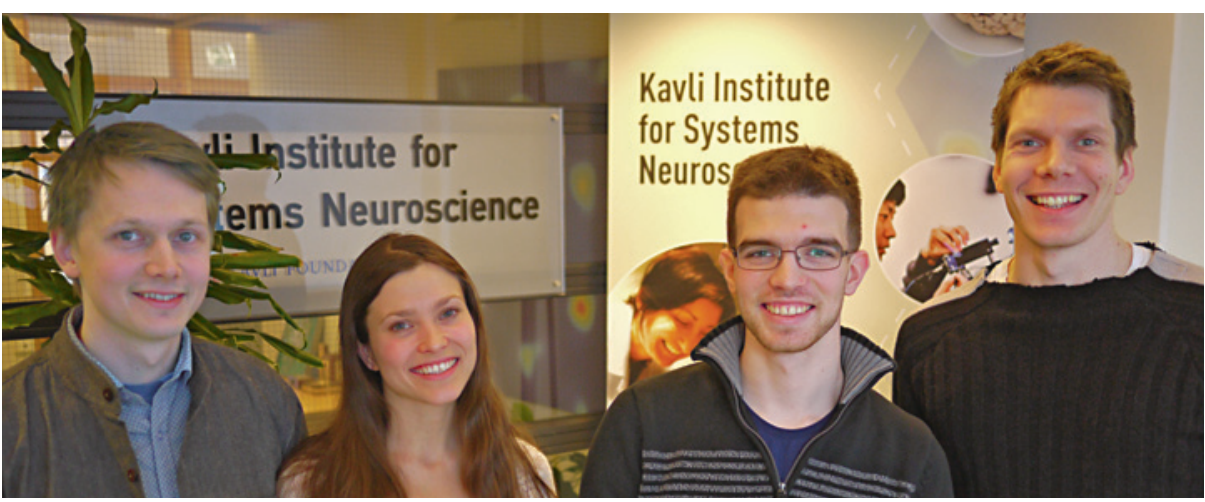

Fire fra prosjektgruppen. Fra venstre Tor Stensola, Hanne Stensola, Kristian Frøland og Trygve Solstad. Foto Haagen Waade, Kavli-instituttet

\title{
Stedsansen består av flere uavhengige komponenter
}

Stedsansen er lokalisert i et lite område i hjernens mediale temporallapp og er organisert i flere funksjonelle moduler.

Mediale entorhinale cortex er et lite område i hjernen som er ansvarlig for det vi kjenner som stedsans. Nervecellene som underbygger den romlige oppfattelsen kalles gitterceller. Aktiviteten i disse cellene styres etter hvilke bevegelser individet gjør og danner et koordinatsystem over miljøet rundt oss. Disse rutenettmønstrene kjennetegnes ut fra avstanden mellom krysningspunktene (skala) og ved mønsterets orientering i forhold til rommet.

Forskere ved Kavli-instituttet for systemnevrovitenskap og Senter for hukommelsesbiologi ved Norges teknisk-naturvitenskapelige universitet har undersøkt hvordan systemet av gitterceller arbeider ved å kartlegge den naturlige variasjonen i mønstrenes skala og orientering langs mediale entorhinale cortex (1). I rotteforsøk ble gittercellenes elektrofysiologiske aktivitet registrert under normal utforskende atferd ved hjelp av implanterte mikroelektroder.

- Ved å kombinere to ulike typer implantater, noen med dybdebevegelige mikroelektroder samlet $i$ ett punkt og andre med multiple elektroder spredt over større områder, oppnådde vi en nær tidobling av celleopptak i forhold til tidligere studier. Målingene avslørte at gitterceller er organisert i et fåtall funksjonelle moduler med felles skala og orientering innen samme modul, og med klare forskjeller i mønstrene mellom moduler, sier Kristian Frøland, som er forskerlinjestudent og medforfatter av artikkelen.

I tillegg viste det seg at gittermodulene reagerte uavhengig av hverandre på endringer i testmiljøet, noe som tyder på at modulene fungerer hver for seg. Forskerne identifiserte opptil fire slike moduler, men størrelsene på økningene i mønsterskala mellom gittermodulene kombinert med den anatomiske dekningsgraden, tilsier at hjernen kan inneholde så mange som ti komponenter av stedsansen.

- At stedsansen har flere moduler, har konsekvenser for hvordan romlig informasjon behandles nedstrøms i hippocampus. Der samles informasjon fra et fåtall gittermoduler med ulike mønstre og gir opphav til unike, stedsspesifikke nevrale koder som legger grunnlaget for danningen av episodiske minner, sier Frøland.

\section{Forskergruppen}

Studien ble utført ved Kavli-instituttet for systemnevrovitenskap og senter for hukommelsesbiologi ved Norges teknisk-naturvitenskapelige universitet i Trondheim. Prosjektgruppen besto av ph.d.-studentene Hanne Stensola og Tor Stensola, som er artikkelens førsteforfattere, postdoktor Trygve Solstad, lege- og forskerlinjestudent Kristian Frøland og professorene May-Britt Moser og Edvard Moser. Prosjektet ble støttet gjennom en Advanced Investigator Grant fra det europeiske forskningsrådet (CIRCUIT, tildelingsavtale nr. 232608), Kavli-stiftelsen og Norges forskningsråd gjennom ordningen med sentre for fremragende forskning.

\section{Hanne Støre Valeur}

hanne.store.valeur@legeforeningen.no Tidsskriftet

\section{Litteratur}

1. Stensola H, Stensola T, Solstad T et al. The entorhinal grid map is discretized. Nature 2012; 492 $72-8$.
Ordforklaringer

Medial entorhinal cortex: En del av Brodmanns område 28, som grenser til hippocampus i den mediale temporallapp. De overflatiske hjernebarklagene 2-3 er rike på gitterceller og gir opphav til robuste projeksjoner til hippocampus. De dype lagene 5-6 mottar informasjon tilbake fra hippocampus.

Gitterceller: En gittercelle (grid cell) er aktiv på flere små steder i rommet man beveger seg i. Aktiveringsstedene er organisert i et sekskantet rutenettmønster som likner på knutene i et fiskegarn. Gittercellenes rutenettmønstre kjennetegnes blant annet ved en viss skala, altså avstanden mellom krysningspunktene, og ved mønsterets orientering i forhold til rommet (se bildet under).

Modul: En modul i medial entorhinal cortex utgjøres av gitterceller som blant annet har liknende skala og orientering av gitteret og som reagerer likt på en gitt geometrisk forandring av det eksterne rom. Gittercellene behøver ikke være anatomiske naboer for å tilhøre samme modul.

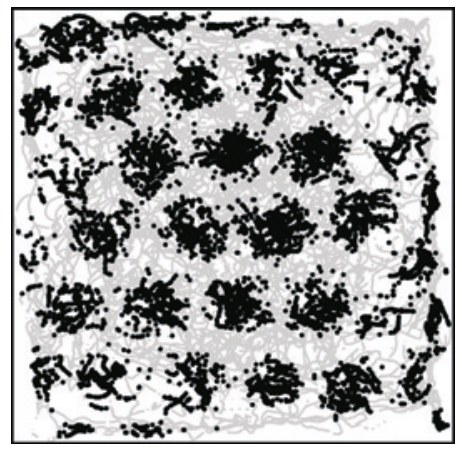

> Her har en rotte utforsket en boks med 2,2 m lange sider i 40 minutter. De grå strekene og svarte prikkene viser hvor rotta har løpt: Hver av de svarte prikkene markerer ett aksjonspotensial (eller nervesignal) fra denne gittercellen

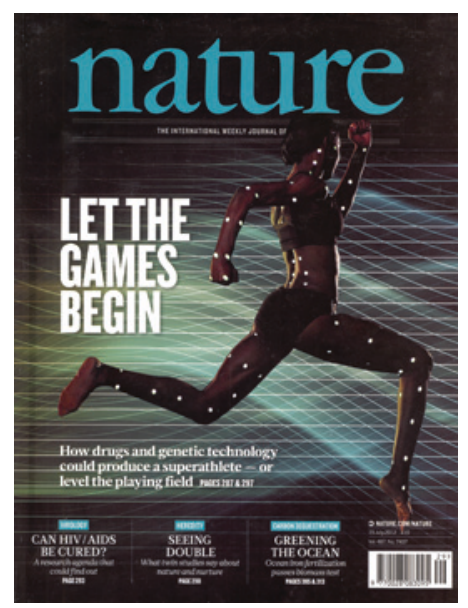

Artikkelen ble publisert i desember 2012 i det prestisjetunge tidsskriftet Nature 